\title{
RETAILING IN BANGLADESH: EVOLUTION AND EXPANSION
}

\author{
Professor Dr. Mohammed Tareque Aziz ${ }^{1}$ 迥 \\ ${ }^{1}$ Center for Service Quality Enhancement (CSQE), Bangladesh
}

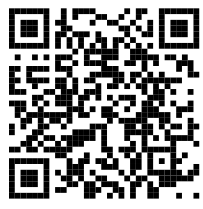

Received 5 May 2021

Accepted 20 May 2021

Published 31 May 2021

Corresponding Author

Professor Dr. Mohammed Tareque

Aziz, tazizdab@yahoo.com

DOI $10.29121 /$

ijetmr.v8.i5.2021.955

Funding: This research received no specific grant from any funding agency in the public, commercial, or not-for-profit sectors.

Copyright: (C) 2021 The Author(s). This is an open access article distributed under the terms of the Creative Commons Attribution License, which permits unrestricted use, distribution, and reproduction in any medium, provided the original author and source are credited.

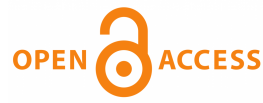

\section{ABSTRACT}

Clothing manufacturers in Bangladesh are known around the world for their low prices. As a destination for clothing sourcing from foreign retailers, it offers low labor costs and a large pool of human resources. This makes Dhaka a sourcing hub for global apparel buyers and retailers. Major clothing retailers in top urban destinations across the Western Hemisphere exclusively display these products in front of their customers. In an effort to develop a theoretical framework to explain Bangladesh's retail industry, three main theories can be outlined. Essentially, these theories propose that as a result of external forces (such as environment or conflict), a retail institution will develop into another type or a new type will develop because of a need, conflict, or other factors. When explaining the international expansion of Bangladeshi retailers, we intended to look at three specific theoretical frameworks ie; Environmental theory, Cyclical theory and Conflict theory. The article has gone through available literatures to establish relationships between there interrelated theories and justify their selection to explain the evolution and expansion of retail industry in Bangladesh.

Keywords: Retailing, Retail Marketing, Evolution Theories

\section{INTRODUCTION}

Several retail fashions brands source their products from Bangladesh, including Zara, Adidas, Wal-Mart, H\&M, Tesco, M\&S, JC Penny, IKEA, LI \& Fung, and Uniqlo Ahmed (2010). North America and Europe are the two main markets for this country's products. Exports to the United States total 46\%, to Canada 14\%, and European markets the remaining Islam (2015). Furthermore, Australia, Japan, China, and Latin America have become significant markets for sourcing as well. Ahmed (2010). Exports from Bangladesh mostly consist of basic clothing items like shirts, T-shirts, underwear, trousers, and sweaters. There are two broad categories of readymade garments export from Bangladesh: woven and knit. Woven clothing includes shirts, pants, and trousers. While T-shirts, polo shirts, sweaters, socks, underwear, and stockings 
are other examples of knitted products. The country's export earnings remain dominated by woven garments, but knitted products are also increasing rapidly, contributing to $40 \%$ of overall revenue now Islam (2015).

Bangladesh's apparel industry emerged during the early 1980s. In Bangladesh, Late Nurool Quader Khan was well known as a pioneer in the readymade garment industry Tribune (2014). On a trip to South Korea in 1978, he and a group of colleagues visited a sewing factory and saw women working at sewing machines. They immediately realized even Bangladeshi women could perform this task. Ultimately, Quader signed a deal with Daewoo and later sent 130 trainees to Korea to learn the skills of manufacturing readymade garments. Mr. Quader, guided by Daewoo trainer Kim Eun Hee, founded Desh Garments, the country's first export-oriented garment industry. for Social Equity Society (2013). Founded by Late Mohammad Reaz Uddin, Reaz Garments is another RMG pioneer. Over time, garment factories such as Stylecraft Limited by Shamsur Rahman, Aristocrat Limited by AM Subid Ali, and Azim Group by Engineer Mohammad Fazlul Azim continued to grow Islam (2015). Upon observing the success of the initial entrepreneurs, some other hardworking and discreet professionals began their RMG businesses, and the industry rapidly grew. Currently, clothing garments are Bangladesh's largest industry in terms of foreign earnings and job creation. According to export data of 2007, this sector accounted for the fourth largest share of the global clothing market (WTO). After China, the EU nations, and Turkey, Bangladesh has become a global center for the sourcing of Readymade Garments Ahmed (2010).

By the end of 2012, Bangladesh's garment exports topped USD 19.9 billion, compared with USD 6.8 billion in 2005, USD 10 billion in 2007, and USD 12.59 billion in 2009. This represents a compound annual growth rate (CAGR) of $16.6 \%$ from 2005 to 2012. A report on exports from 2014 shows their value was 24.49 billion USD. Despite the multiple domestic and global challenges Bangladesh has faced in the last 15 years, readymade garments exports have taken the country beyond even the most optimistic predictions Star (2015). This indicates an extremely bright future for Bangladesh's garment exports. US fashion companies plan to increase their sourcing from Bangladesh in the next two years, according to a survey conducted by the United States Fashion Industry Association (USFIA) and the University of Rhode Island. According to McKinsey, Bangladesh is the next hot spot in the apparel manufacturing industry. By 2020, the firm predicts export-value growth of up to 7-9\% per year, but this is contingent on overcoming several challenges- skilled workforce and developing infrastructure are some of these priorities Tribune (2014).

Considering this performance and the CAGR growth rate of 14\%, Bangladesh has the potential to surpass its USD 50 billion target by $2021 \mathrm{Star}$ (2015). Bangladesh has experienced strong growth in its RMG sector, having grown by an average of $6 \%$ per year. As a result, the country has developed a strong middle class, which has resulted in a loyal clientele for Bangladesh's clothing industry. Since the advent of globalization, trade liberalization, changing shopping behavior, urbanization, the rise in 
middle-class consumers, and government policies favoring imports, retail business has undergone significant changes Hussain and Ara (2004). By 2021, retail superstores in Bangladesh are predicted to generate 2.55 billion US dollars in sales with a $30 \%$ yearly growth rate (Jinnat, 2016). In a report published on January 7,2013 , the Daily Sun notes that the Bangladeshi middle class includes at least 30 million people that is, $20 \%$ of the population, which is higher than in Denmark, Sweden, or Norway. As middle-class and upper-class lifestyles change, Bangladesh's clothing retail industry is expected to become a catalyst for the country's transport, infrastructure, and supply chain development.

Retail trade is considered a traditional business in Bangladesh that accounts for around $10 \%$ of total sales. In most cases, our retail companies were born from RMG projects that were primarily motivated by short-term profits. Nonetheless, the situation has improved while modern retailers have increased their revenue by $15 \%$ annually. And by 2020, the turnover of modern retail will grow fourfold to US $\$ 37$ billion, according to a recent study "Online publication" (2014). Even in the past decade, millions of unorganized small-scale traders dominated the retail trade sector in Bangladesh. As a result of the rapid urbanization, the retail market is also becoming more modern. Although organized clothing retailing has huge growth prospects, the pace of growth is much slower than elsewhere in the world.

However, compared to its Asian counterparts, the Bangladeshi retail industry is still in its infancy. In addition, as the economy expands, so does the retail industry of the country, as well as the positive changes in the consumption patterns of the middle-class. In Bangladesh, businesses in the retail sector are mostly familyrun firms with limited growth prospects. Despite the lack of information available on the progress of this sector, Hussain \& Ara (2013) have suggested an average of $7 \%$ growth. In light of rapid globalization among urban populations, the clothing retail industry has expanded and become a sector with enormous growth potential. Hussain \& Leihman (2013) distinguished five major types of retailing in Bangladesh. They include temporary shops, roadside stands, stores in municipal corporations, convenience stores, and supermarkets. Bangladesh, as a less developed country (LDC), has seen much change in its retail landscape over the past two decades. Taking its neighbors' lead, Bangladesh has opened up its economy to global forces. This has resulted in her replacing pro-socialist economic policies with liberal and promarket ones. Incentives like cheap labor, cheap land and tax breaks are credited for accelerating modernization. The modernization process was also sped up by the disinvestment of numerous public companies. Retail companies backed by their parent RMG companies make up the majority of them. Globalization of business indicates that expansion of the retail industry will take on greater significance when conducting business internationally. 


\section{MATERIALS AND METHODS}

In an effort to develop a theoretical framework to explain Bangladesh's retail industry, three main theories can be outlined. Essentially, these theories propose that as a result of external forces (such as environment or conflict), a retail institution will develop into another type or a new type will develop because of a need, conflict, or other factors. When explaining the international expansion of Bangladeshi retailers, we intend to look at three specific theoretical frameworks. These are:

1. Environmental theory

2. Cyclical theory

3. Conflict theory

These theories of retail expansion can assist us in identifying an appropriate theory that can help us explore avenues that can inspire our retailers to expand their business internationally. Initially, in many Western countries, various types of retail institutions developed and expanded over time, for example, department stores and discount stores, which were transported internationally in a short time period. Furthermore, the size of Bangladesh's land and its concentration of people is different from those of Europe and the US, where land size is bigger and population density is lower. The majority of retail evolution studies draw their data from the United States and European markets. In addition, Bangladesh has been ostracized by the government and has different political isolation as compared to more liberalized markets in Western civilizations, which gave rise to most types of retail institutions.

Retail institutions emerging in Bangladesh are unique in comparison with previous retail institutions. This study will help us understand how to exploit the competitive advantages that emerged with these retailers for an impact on the potential internationalization of local retailers. In light of previous research on retail evolution, this study aims to determine the reasons for change or evolution for various types of retail institutions even though "none of the retail evolution theories have succeeded in providing such knowledge" Brown (1987). Furthermore, Bangladesh has never properly classified retail institutions based on the classification theory. We would like to include them in the evolutionary process as a part of our study. As we learned from the study "Model for the evaluation of retail institution types," written by Sook Hyun Kim, there is a mature retail industry in South Korea (where almost all major western retailers operate). Especially in a third-world nation such as Bangladesh, where the retail industry is in its growing stage, no prior studies exist. The retail evolution theories include:

a) Cyclical theory: The theory states that retail institutions change their attributes, such as prices and products, in rhythmic cycles (i.e., low-high-low cycle or generalspecific-general cycle).

One of the best-known cyclical theories is the Wheel of Retailing theory. In this theory, the price aspect determines retail evolution. The Wheel of Retailing Theory McNair (1958) explains how our retailer has grown internationally by utilizing 
very low labor costs.

b) Conflict theory: In studies explaining retail evolution, many researchers have referred to this theory Berens (1980); Bliss (1967); Cauwe (1979); Gist (1968); Oxenfeldt (1960); Schumpeter (1947); Thomas, 1970). These studies are largely based on observations of retail activities in Europe and the United States, just like those regarding cyclical theories. The Dialectic theory was first proposed by retail researcher Gist (1968) as a theoretical framework for the common concepts of most conflict theories. Karl Marx developed his Theory of Evolution which forms the basis for the Dialectic theory. Using the Dialectic Theory, Gist (1968) substituted a "situation" from the Theory of Evolution for the "retail institution". In his view, a competing retail institution challenges an existing one simply because it has more competitive advantages than it does. In an analysis of conflict theory, it can be argued that Bangladeshi retailers have advantages over foreign, notably South Asian rivals.

c) Environmental theory: Research on the Environmental Theory identifies the retail environment as a significant component influencing retail changes. This suggests that retail institutions have to adapt and survive change and competition (Blizzard, 1976; Brown (1987); Gist (1968); Oren (1989). In the study, researchers wrote that a retail institution would lose its effectiveness if it cannot respond rapidly to environmental changes. In fact, the Natural Selection theory was originally inspired by Darwin. Now, Bangladeshi retailers need global operations, as many South Asian retailers are beginning to expand overseas, or else their international expansion may become extremely difficult to accomplish down the road.

\section{RESULTS AND DISCUSSIONS}

The retail industry can use a mix of different theories to determine the potential of their application. In the past, researchers have experimented with combining the cyclical theory with the environmental theory or conflict theory Cox (1958); Deiderick and Dodge (1983); Gist (1968); Izraeli (1973). There have been a number of researchers who have combined the theories of Conflict and Environment Alderson (1957); Oren (1989). Others have combined the Environmental, Cyclical, and Conflict theories Hunt (1976); Kaynak (1979); Shaw (1978). Brown (1987) strongly emphasized how retail institutions are vulnerable to cyclical changes in the external environment. He heavily supported the Wheel of Retailing theory (i.e., cyclical theory). In his analysis, he found that environmental change (e.g., socioeconomic, governmental, cultural, political, and business structure changes) is the most significant player in the evolution of retail institutions (i.e., Environmental theory). Deiderick and Dodge (1983), providing a theoretical framework for analyzing retail institutions, propose that three characteristics can be identified (price, product range, geography), which are cyclically altered (Cyclical theory), and possible environmental influences on these traits (Environmental theory). 
A modified theory of retailing proposed by researchers such as Izraeli (1973) is known as the Three Wheels of Retailing. In summary, the model had three wheels: low-end innovation, high-end innovation, and conventional retailers at both high and low ends. Based on his analysis of retail evolution, Guiltinan (1974) concludes that the wheel of retailing does not adequately explain all retailing evolution. In addition to the environmental theory aspect, he also included an analysis of competitors (i.e., conflict theory) in explaining retail evolution. Both Alderson (1957) and Brown (1988) supported the idea of merging environmental and conflict theories. Several researchers have proposed combining all three retail evolution theories to explain retail institution evolution Hall et al. (1961); Kaynak (1979); Shaw (1978). Researchers Hall, Knapp, and Winsten gathered U.S., British, and Canadian census data to determine how environmental changes affect retail structure and innovation.

\section{CONCLUSIONS AND RECOMMENDATIONS}

There has been a lot of research done on the development of retail evolution theories mainly related to FMCG, convenience products, and general retail product categories. However, no country to date has tested them in the clothing retail sector. Furthermore, these theories have some limitations, both concerning their study areas and their applications. Many previous researchers propose retail evolution theories as a tool to explain retailers' international expansion activities. However, these theories generally apply to just one or a few types of retail institutions rather than universally. As a consequence, previous proposals lack evidence of generalizability. Retail evolution theories suffer from the same problem of universality, according to Soon and Hyu (2003). The concept of universality does not only apply to different types of retail establishments but it has also been questioned across countries Brown (1987). There have been several studies and articles that attempt to quantify retail evolution theory Ingene (1983); McNair (1958); Shaw (1978). However, these studies are not deemed valid or accurate by other researchers in the area Brown (1987); Gist (1968); Hirschman, 1979; Kaynak (1979); Oren (1989).

Finally, we want to point out that crime and political instability are two major factors hindering the growth of our country's RMG industry in many ways Tribune (2014). Since our retail industry must expand internationally to grow, local retailers could benefit from following the suggestions and guidelines of Gereffi and Memedovic (2003). The study highlighted the changes in global apparel value chains' roles and governance structures. Among these initiatives are:

1. Assembly: The process of supplying imports to garment manufacturers for assembly, typically in export processing zones (EPZs).

2. Manufacturing original equipment: Providing a manufacturing strategy focused on increasing efficiency of processes and improvement of execution.

3. Integrated design manufacturing: Design-driven approach rather than one that is focused on manufacturing or branding. 
4. Authentic brand manufacturing: The notion that design or production is secondary to branding

By emphasizing the following, Bangladeshi retailers can seize the opportunity to compete abroad, as suggested by Gereffi and Frederick (2010):

1. A Brand owner can become a specialty retailer

2. The full-package manufacturers may enter into retail intermediary roles

3. Expanding their role as international agents or intermediaries

4. Increasing private label brands

5. A brand marketer can partner with mass merchant retailers to produce exclusive products for a specified overseas market

6. If indigenous retailers decide to expand abroad, they should think about adapting social and environmental standards in order to gain acceptance in the new market.

7. Several RMG companies from Bangladesh have grown to the point where they are now able to go overseas and start their own businesses. Having worked with buyers from different countries, our companies now have a deep understanding of quality standards, environmental issues, and compliance issues Ahmed (2010). Therefore, why is the Bangladesh brand not being promoted in the foreign market? Having said that, there are several legitimate reasons why our nation's retailers don't go overseas.

8. In this case, competition is the primary challenge. Brands with a global reputation will compete fiercely with our companies. There is the possibility that some Bangladeshi companies will fail due to the difficulty of competing with global brands that include Wal-Mart, Zara, H\&M, etc.

9. Exporting Bangladeshi brands will probably face some issues with overseas brands that also source from Bangladesh.

10. Another issue is the lack of qualified individuals working in the fashion industry as well as the apparel and textile industries in Bangladesh. Though the fashion and apparel industry is flourishing in our country, there are not enough professionals with high knowledge regarding fashion to compete with overseas brands Tribune (2014).

11. Another possible reason could be inefficient management and employees. The main issue here is the fact that educated people in our country do not wish to launch a risky business. For that reason, the less qualified would enter the management sector. This inefficient management significantly affects the business's ability to succeed, and as a result, poor management decisions will lead to business failure.

12. Lack of product diversification and product innovation could also pose a challenge Islam (2015). As far as clothing is concerned, Bangladesh only produces 
the basics, such as shirts, t-shirts, pants, and undergarments. So, the product mix is not diverse. Additionally, the products of the companies should be distinct from those of their competitors in some way; otherwise, competitive advantages would not exist.

These strategies would be hard to implement by Bangladeshi retailers wishing to expand internationally because their companies are accustomed to producing the same products that foreign brands sell, and implementing the same technologies as foreign manufacturers. When the Bangladeshi RMG industry began, entrepreneurs turned to the retail industry for its profits. In the past, they offered several competitive advantages to their international clients, among which the biggest one was the cost advantage. Additionally, integration into value chains, advantages in pricing through multiple suppliers, direct control over production shed, improved flexibility to meet fluctuating demand, better control of commercial risk, and added value to the business were other advantages. However, when RMG owners choose to venture into the global market, they are going to encounter obstacles related to quotas, duty rates, wage structure, ethical issues, distance, economic and political stability, etc.

\section{REFERENCES}

Ahmed, A. (2010). Branding of Bangladeshi clothing: Are we ready?". Bangladesh textile today. [Blog post].

Alderson, W. (1957). Marketing behavior and executive action (R. D. Irwin, Ed.). Homewood, IL.

Berens, J. S. (1980). Capital requirements and retail institutional innovation - Theoretical observation". Theoretical developments in marketing. Chicago, IL: American Marketing Association.

Bliss, P. (1967). Schumpeter, the big disturbance and retailing (R. R. Gist, Ed.). New York: John Wiley.

Brown, S. (1987). Institutional Change in Retailing: A Review and Synthesis. European Journal of Marketing, 21(6), 5-36. Retrieved from https://dx.doi.org/10.1108/ eum0000000004701 10.1108/eum0000000004701

Cauwe, M. (1979). The life cycle of the retail business. Retail and Distribution Management, 7(4), 48-51. Retrieved from https://dx.doi.org/10.1108/eb018004 10.1108/ eb018004

Cox, R. (1958). Competitive distribution in a free high-level economy and its implications for the university". Pittsburg: University of Pittsburg Press.

Deiderick, T. E., \& Dodge, H. R. (1983). The wheel of retailing rotates and moves". Marketing: Theories and concepts for an era of change. Carbondale: Southern Marketing Association.

for Social Equity Society, R. I. (2013). How the garments industry came to Bangladesh. Online publication of RISES, November.

Gereffi, G., \& Frederick, S. (2010). The Global Apparel Value Chain, Trade and the Crisis: Challenges and Opportunities for Developing Countries.

Gereffi, G., \& Memedovic, 0. (2003). The Global Apparel Value Chain: What Prospects for Upgrading for Developing Countries (Report). United Nations Industrial Development 
Organization.

Gist, R. R. (1968). Retailing: Concepts and decisions". New York: John Wiley and Sons.

Global value chains in a postcrisis world. (n.d.). In Cattaneo \& G. G. C. Staritz (Eds.), (pp. 157208). World Bank.

Guiltinan, P. (1974). Planned and evolutionary changes in distribution channels". Journal of Retailing, 50(2).

Hall, M., Knapp, J., \& Winsten, C. (1961). Distribution in Great Britain and North America: A study in structure and productivity. London, England: Oxford University Press.

Hunt, S. D. (1976). Marketing theory: Conceptual foundations of research in marketing (Unpublished master's thesis). Columbus: Grid.

Hussain, S., \& Ara, F. (2004). Bangladesh retail food sector report. USDA Foreign Agricultural Service GAIN report.

Ingene, C. A. (1983). Intertype competition: Restaurants versus grocery stores". Journal of Retailing, 59(3).

Islam, K. (2015). Readymade garments industry of Bangladesh. Merchandising: Online library for merchandisers, September.

Izraeli, D. (1973). The three wheels of retailing: a theoretical note. European Journal of Marketing, 7(1), 70-74. Retrieved from https://dx.doi.org/10.1108/eum0000000005101 10.1108/eum0000000005101

Kaynak, E. (1979). A Refined Approach to the Wheel of Retailing. European Journal of Marketing, 13(7), 237-245. Retrieved from https://dx.doi.org/10.1108/eum0000000004957 10.1108/eum0000000004957

McNair, M. P. (1958). Significant trends and developments in the postwar period. University of Pittsburgh Press.

Online publication. (2014). Euromonitor International.

Oren, C. (1989). The dialectic of the retail evolution. Journal of Direct Marketing, 3(1), 15-29. Retrieved from https://dx.doi.org/10.1002/dir.4000030105 10.1002/dir .4000030105

Oxenfeldt, A. R. (1960). The retailing revolution: Why and whither". Journal of Retailing, 36.

Schumpeter, J. A. (1947). Capitalism, socialism, and democracy. London: Gorge Allen and Unwin.

Shaw, G. (1978). Processes and patterns in the geography of retail change.

Soon, \& Hyu, K. (2003). Consumer product search and purchase behavior using various retail channels. International journal of consumer studies, 32(6).

Star, T. D. (2015). Future of RMG trade in Bangladesh. 24th Anniversary of the daily star (part1).

Tribune, D. (2014). RMG industry of Bangladesh: past, present and the future. Online publication of Dhaka Tribune, September. 